Article

\title{
Economic Evaluation on Bio-Synthetic Natural Gas Production Integrated in a Thermomechanical Pulp Mill
}

\author{
Wennan Zhang *, Jie He, Per Engstrand and Olof Björkqvist \\ Received: 13 August 2015 ; Accepted: 2 November 2015 ; Published: 12 November 2015 \\ Academic Editor: Robert Lundmark \\ FSCN_Fibre Science and Communication Network, Mid Sweden University, Sundsvall SE-85170, Sweden; \\ jie.he@miun.se (J.H.); per.engstrand@miun.se (P.E.); olof.bjorkqvist@miun.se (O.B.) \\ * Correspondence: wennan.zhang@miun.se; Tel.: +46-101-428-639; Fax: +46-101-428-820
}

\begin{abstract}
In this study, biorefinery as a concept is applied to thermomechanical pulp (TMP)-based paper production to evaluate the possibility of co-production of synthetic natural gas (SNG), electricity and district heating in addition to mechanical pulp and paper. The combined heat and power plant (CHP) associated to TMP is replaced by a biomass-to-SNG (BtSNG) plant. Implementing BtSNG in a mechanical pulp production line might improve the profitability of a TMP mill and also help to commercialize the BtSNG technology by taking into account of some key issues such as biomass availability, heat utilization, etc. A TMP + BtSNG mathematical model is developed with ASPEN Plus. The model prediction shows that the scale of the TMP + BtSNG mill and SNG price are two strong factors for the implementation of BtSNG in a TMP mill. A BtSNG plant associated to a TMP mill should be built at a scale above $100 \mathrm{MW}$ of biomass thermal input. For the case of Swedish economic condition, commercialization of SNG production as a transport biofuel has not matured yet. Political instruments to support commercialization of transport biofuel are necessary.
\end{abstract}

Keywords: biomass; gasification; synthetic natural gas (SNG); thermomechanical pulp (TMP); electricity

\section{Introduction}

The possibility of producing transport fuels from biomass and wastes has become a more and more important issue with regard to the global challenges of energy security and climate change. The present transportation biofuels on the market are produced mainly from food crops, referred to as the 1st generation biofuels, which are not encouraged any longer in Europe Union (EU) after the EU directive on the biofuels sustainability criteria in 2009. From the viewpoint of economics, the environment, land use, water use, chemical fertilizer use, etc., however, there is a strong preference for the second generation biofuels that are produced using woody, grassy materials as well as agricultural residues, municipal wastes and industrial wastes as feedstocks. Thus, the production of synthetic transport fuels such as methanol, ethanol, dimethyl ether, Fischer-Tropsch fuel and synthetic natural gas (SNG) via gasification and synthesis is promising [1]. Production of these fuels from coal and natural gas has been successfully commercialized, e.g., by Sasol and Mobil [2]. For biomass, however, the technology has not been established, mainly due to the high production cost for limited scale biomass-based plants.

Among the abovementioned fuels, bio-SNG can be produced easily since the once-through methanation conversion efficiency is high even under moderate pressure and temperature conditions and a sophisticated upgrading of products is not needed. Thus, biomass to SNG (BtSNG) can be 
realized commercially with a medium scale of around $100 \mathrm{MW}$ in comparison to the large scale of thousands of MW in fossil fuel plants.

For an extremely small scale, the German company, Agnion, offers bio-SNG plants based on a heat-pipe reformer concept with a capacity of approximate $3 \mathrm{MW}$ bio-SNG [3]. The isothermal fluidized bed methanation developed at the Paul Scherrer Institute and commercialized by Clean Technology Universe was demonstrated with a scale of $1 \mathrm{MW}$ in Güssing in 2009. A larger scale demonstration plant of $20 \mathrm{MW}$ bio-SNG output has been put into operation at the end of 2014 in Gothenburg as the GoBiGas project, which is scheduled to scale up to 100 MW bio-SNG plant in 2016. A bio-SNG plant of $200 \mathrm{MW}$ is planned in the E.ON Bio2G project. Depending on technology, scale, and energy prices, the most economic configuration may provide a net SNG yield of $66 \%$ to $75 \%$ from wood (based on lower heating value (LHV) of the dry substance). The poly-generation of fuel, heat, and power allows for a total useful energy yield ranging from 71\% to 91\% [4]. Bio-SNG can be used in a variety of applications:

- Grid injection;

- Vehicle fuel;

- Chemical feedstock;

- Fuel for electricity or heat production.

In Sweden, Germany and many other countries, biogas produced from waste treatment through digestion has been used in the market as a vehicle fuel. The scale has expanded rapidly in recent years. This provides an excellent infrastructure and market opportunity for bio-SNG production as a transport fuel.

High yield pulp (HYP) is the denotation for processes such as stone groundwood (SGW), pressure groundwood (PGW), thermomechanical pulp (TMP) and chemothermomechanical pulp (CTMP). The wood to final pulp yield ranges from $85 \%$ to $98 \%$ which is much higher than typical chemical pulp processes that normally have a yield of about 50\%. TMP, SGW, PGW and recycled paper-based pulp (deinked pulp-DIP) are mostly used in printing papers, while CTMP is used in many different paper and packaging grades (printing, paperboard, tissue, fluff). The drawback with HYP processes is that they are the most electrical energy-intensive processes in the pulp \& paper industry, with an electricity consumption of 2-3 MWh/t. CTMP-process electricity consumption ranges from $0.7 \mathrm{MWh} / \mathrm{t}$ to $2 \mathrm{MWh} / \mathrm{t}$, depending on the final product. It should however be emphasized that up to about $70 \%$ of the electricity consumption is regained as low-pressure steam that is used for drying of the paper products. To substantially reduce specific electricity consumption (SEC) while maintaining pulp quality is therefore the most important issue for the high-yield pulp and paper industry [5]. The Fibre Science and Communication Network (FSCN) at Mid Sweden University, together with Scandinavian forest and pulp \& paper companies and research institutes, is running a large research program with the goal of showing how to design the TMP and CTMP production lines of the future to reduce SEC by $50 \%$. Today, some logging residues (branches and tree tops) are utilized as a source of bioenergy, but the major part of the logging residues remains in the forest in many countries, e.g., Sweden. The logging residues represent about $30 \%$ of the biomass of the felled trees. Most of the bark ( $>10 \%$ of the log biomass) follows the logs to the pulp- or sawmills to be used in combined heat and power plants (CHPs). Due to fiber morphology reasons about $10 \%$ of the fiber material in the final pulp has a negative influence on the final product properties [6]. The possibilities of utilizing not only bark, but also branches and tops as well as the pulp fibers with negative impact on paper properties as a source of bioenergy has not been evaluated. The total potential amount of biomass available is thus about 0.66 ton per ton of pulp and 0.84 ton if $10 \%$ low quality pulp fibers are also used (normally, only the bark, shavings, and biosludge are utilized in present bark boilers of CHP systems of TMP mills).

A previous study investigated the profitability of a TMP mill integrated with a biomass integrated gasification combined cycle (BIGCC) for electricity generation [7]. In the present study, 
the feasibility of biomass gasification-based technology to produce $\mathrm{CH}_{4}$ in a TMP mill is evaluated and compared with TMP + BIGCC in terms of the technical and economic aspects.

A TMP + BtSNG mathematical model is developed with ASPEN Plus. By means of modeling, three cases are studied:

1) Scaling of the TMP + BtSNG mill;

2) Adding the reject fibres in the gasifier;

3) Decreasing the TMP-specific electricity consumption (SEC) by up to $50 \%$.

The profitability of the TMP + BtSNG mill is analyzed in comparison with a previously studied TMP + BIGCC mill.

\section{Process Design and Simulation}

\subsection{Thermomechanical Pulp (TMP) + Paper Mill (PM)}

A paper mill (PM) with a TMP process has a very high wood-to-pulp/wood-to-paper yield $(>95 \%)$, but consumes a large amount of electricity (about 2.5 MWh per ton of pulp in TMP and 0.75 MWh per ton of paper in PM as given in Table 1).

Table 1. Outline of a thermomechanical pulp (TMP) and paper mill (PM) [8].

\begin{tabular}{|c|c|c|}
\hline Mass/energy & TMP & PM \\
\hline Yield & $230,000 \mathrm{t} /$ year & $250,000 \mathrm{t} /$ year \\
\hline Pulpwood with Bark & $250,000 \mathrm{t} /$ year & - \\
\hline Pulpwood & $220,000 \mathrm{t} /$ year & - \\
\hline Biomass Residues & - & $3.9^{\text {a }} \mathrm{MWh} /$ bdt pulp \\
\hline Electricity consumption & $2.5 \mathrm{MWh} / \mathrm{bdt}$ pulp & $0.75 \mathrm{MWh} / \mathrm{bdt}$ pulp \\
\hline production & 1.2 MWh/bdt pulp & - \\
\hline consumption & $0.03 \mathrm{MWh} / \mathrm{bdt}$ pulp & $1.38^{\mathrm{b}} \mathrm{MWh} / \mathrm{bdt}$ pulp \\
\hline
\end{tabular}

\section{Biomass Residues}

\section{logging residues, bark, bio-sludge and reject fibers}

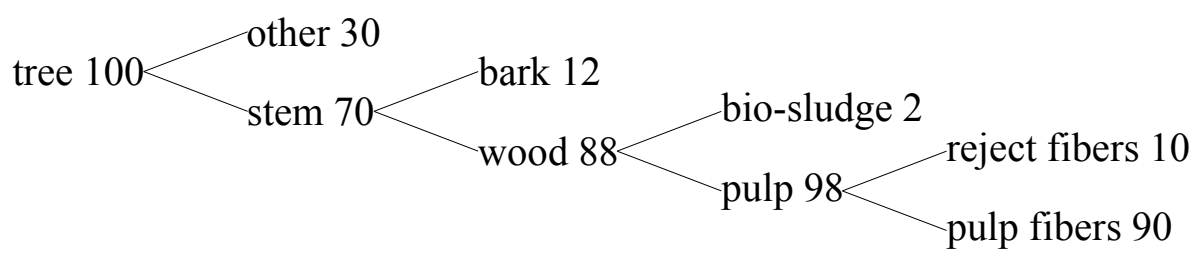

Figure 1. Available biomass residues in a TMP mill.

Since a TMP process is normally integrated with paper production, the electricity consumed in the refining process is simultaneously utilized to obtain hot water and steam for paper drying. Some of the input data to this model are from a TMP + PM mill of Holmen Paper in Hallsta [8], as presented in Table 1.

Biomass residues from a TMP + PM mill are traditionally utilized through a CHP plant to supply the mill electricity and steam. The original CHP plant is intended to be replaced by a BtSNG plant in the model. Figure 1 illustrates the source of the biomass residues available for the gasification plant associated to a TMP mill. The available biomass residues are significant and include: 
1) Logging residues, amounting to $30 \%$ of the tree;

2) Bark, $12 \%$ of the stem;

3) Bio-sludge, $2 \%$ of the pulpwood; and

4) Reject fibers, $10 \%$ of the pulp.

As a result, 0.84 ton of biomass residues are available from the production of each ton of pulp. Additional biomass (including peat) can be gained from other applications, e.g., the production of chemical pulp, which are not taken into account in the economic evaluation of this work.

\subsection{Biomass-to-Synthetic Natural Gas (BtSNG)}

Before setting up a mathematic model, a BtSNG process flow diagram is designed as shown in Figure 2. The process is established with five steps: biomass pretreatment, gasification, syngas cleaning and conditioning, SNG synthesis, and separation and purification. This system includes a steam turbine system to utilize the waste heat from BtSNG to generate electricity and steam for the use in a TMP + PM mill.

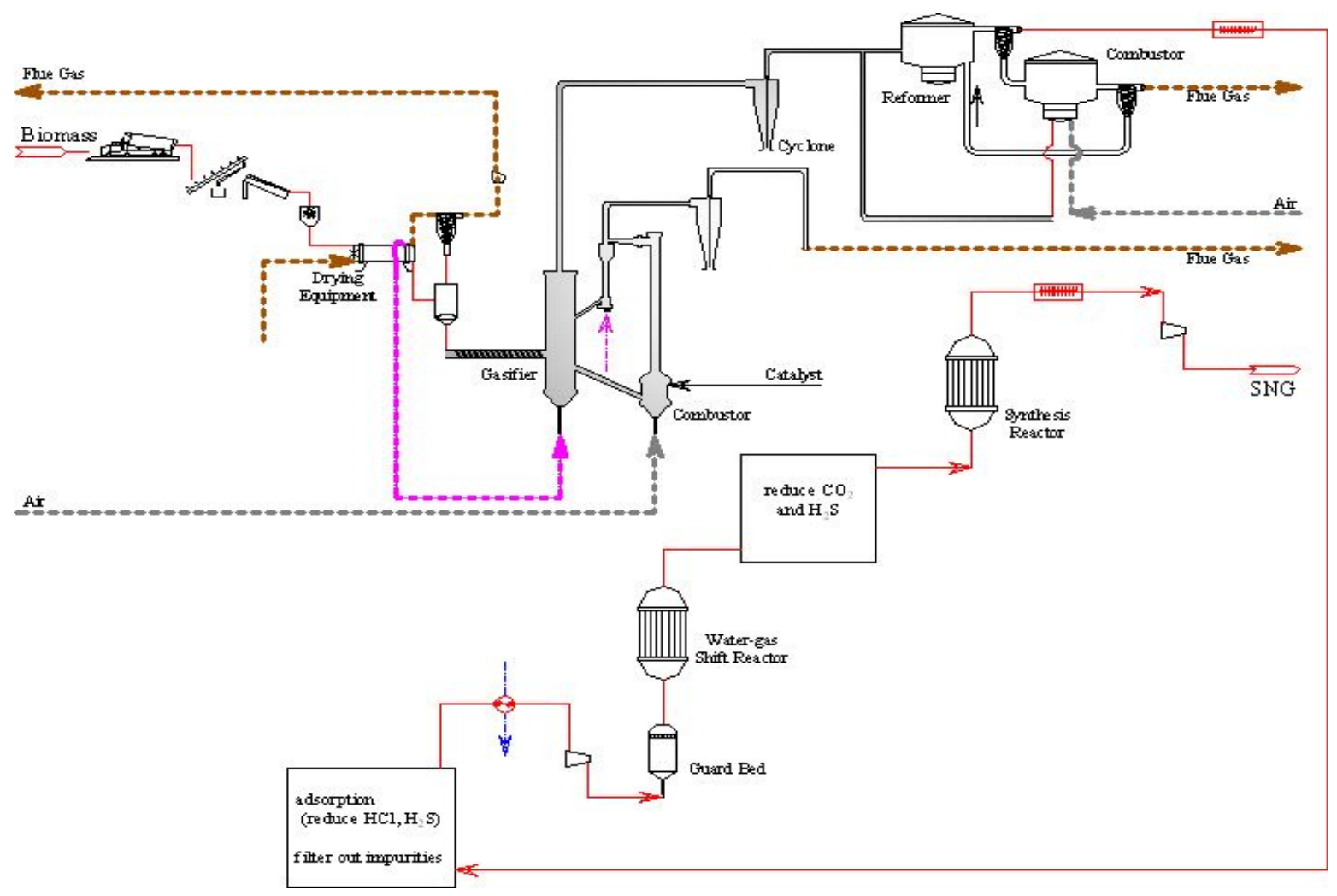

Figure 2. Model of biomass-to-synthetic natural gas (BtSNG) with a fluidized-bed SNG synthesis system.

\subsubsection{Biomass Pretreatment}

Fresh biomass has a high moisture content of up to $50 \mathrm{wt} \%$, is inhomogeneous in shape and size, and needs pretreatment before being fed to a gasifier. The pretreatment process is illustrated in Figure 2. Biomass chips are weighed and screened. Metal debris is removed through a magnetic separator. Particles larger than $10 \mathrm{~mm}$ are conveyed to a hammer mill for further size reduction. Wet biomass is dried by utilizing the waste heat from the TMP and BtSNG plants. Before being pumped to the atmosphere, the exhausted flue gas passes through a cyclone to separate some particulates. The temperature of the stack flue gas is controlled. 


\subsubsection{Gasification}

In this study, a dual fluidized bed gasifier (DFBG), so called indirect gasifier, is chosen for biomass gasification. It consists of a bubbling fluidized bed gasifier and a circulating fluidized bed combustor. Production of high-quality syngas from biomass gasification in DFBGs has made a significant progress in R\&D and technology demonstration. A small and medium (S\&M) scale bio-automotive fuel plant close to the feedstock resources is preferable as biomass feedstock is quite sparse and has relatively low density, low heating value and high moisture content. This requires a simple, reliable and cost-effective production of clean and good quality syngas. Indirect DFBGs, with steam as the gasification agent, produces a syngas of high $\mathrm{H}_{2}$ and $\mathrm{CO}$ content with $12-20 \mathrm{MJ} / \mathrm{Nm}^{3}$ heating value. Good quality syngas from DFBGs can be obtained by optimized design and operation of the gasifier, by the use of active catalytic bed materials including those for internal reforming of tars, and finally by a downstream cleaning process. Olivine is a suitable bed material with enough resistance to attrition and moderate tar cracking activity. The DFBG gasification opens a possibility to produce syngas suitable for methanation at an S\&M scale. However, in order to produce bio-SNG, extensive gas cleaning is needed.

\subsubsection{Gas Cleaning}

Syngas cleaning is the key issue for commercialization of biomass gasification technology, and has been reviewed by many researchers [9]. Raw syngas contains various impurities such as tars, sulfurous and nitrogenous compounds, alkali metal species, ash, and char. These impurities are potential threats to methanation catalysts. The cleaning process designed in the model is illustrated in Figure 2.

Firstly, the syngas passes through a high temperature particle filter, and the tars in the syngas are cracked down by a monolith $\mathrm{Ni}$ catalytic reformer before syngas temperature drops. The tar reformer operates isothermally at $710-890^{\circ} \mathrm{C}$ [10]. The reforming unit consists of a catalytic reformer and a catalyst regenerator. Energy for endothermic reforming is transferred from the circulating catalytic bed material that acts as heat carrier as well. The reformed syngas flows through a cyclone and is cooled to $150{ }^{\circ} \mathrm{C}$, while the flue gas from the regenerator is sent to a biomass drier through another cyclone. The tars can also be stripped of vegetable oil, and the spent scrubber liquid saturated with tar and condensate is vaporized and recycled to the combustor coupled with the gasifier. The syngas is further cleaned via water scrubbing, and impurities like particulates, residual tars and ammonia are further reduced. Subsequently, the syngas is compressed to the pressure of methanation reactor leaving $\mathrm{NH}_{3}$ and $\mathrm{H}_{2} \mathrm{O}$ condensed. Afterwards, acid gases $\left(\mathrm{CO}_{2}\right.$ and $\left.\mathrm{H}_{2} \mathrm{~S}\right)$ removal is carried out in an amine-based absorption (MEA) system. A CO-shift unit is used to adjust $\mathrm{H}_{2} / \mathrm{CO}$ molar ratio. The investment and operating cost for the gas cleaning is discouraging, especially if one moves to the smaller plant sizes.

\subsubsection{Methanation}

Methanation can be either carried out in a series of adiabatic fixed bed reactors with inter-cooling and optional product recycle, or in a single fluidized bed reactor under isothermal conditions [11]. Ni-based catalysts are commonly used. Methanation is highly exothermic $[12,13]$. The temperature should be generally kept low to favor the equilibrium. It should be considered that the temperature is limited by the catalyst activation and carbon deposition problems. The operation is also limited by catalyst sintering problems at higher temperatures. The fixed bed methanation is operated at temperature around $650{ }^{\circ} \mathrm{C}$, whereas the fluidized bed methanation around $300^{\circ} \mathrm{C}$.

A higher pressure is favorable for $\mathrm{CH}_{4}$ formation. The operation at a higher pressure increases the methanation conversion efficiency and reduces the amount of catalyst required. For adiabatic fixed bed methanation, the pressure should be high, about $10 \mathrm{bar}$, corresponding to the high temperature. For fluidized bed methanation, on the other hand, the pressure should be low, about 
4 bar, corresponding to its low temperature. A high conversion efficiency of methanation can also be achieved even at atmospheric pressures. A compression stage prior to the methanation stage ensures the necessary pressure for final SNG delivery to a local distribution network, otherwise, additional compression of final SNG is needed [11,13].

Methanation Reactions [14]:

$$
\begin{gathered}
\mathrm{CO}+3 \mathrm{H}_{2} \rightleftharpoons \mathrm{CH}_{4}+\mathrm{H}_{2} \mathrm{O}, \Delta \mathrm{H}_{298}^{\ominus}=-206 \mathrm{~kJ} / \mathrm{mol} \\
\mathrm{CO}_{2}+4 \mathrm{H}_{2} \rightleftharpoons \mathrm{CH}_{4}+2 \mathrm{H}_{2} \mathrm{O}, \Delta H_{298}^{\ominus}=-165 \mathrm{~kJ} / \mathrm{mol} \\
\mathrm{C}+2 \mathrm{H}_{2} \rightleftharpoons \mathrm{CH}_{4}, \Delta H_{298}^{\ominus}=-75 \mathrm{~kJ} / \mathrm{mol} \\
2 \mathrm{CO} \rightleftharpoons \mathrm{C}+\mathrm{CO}_{2}, \Delta H_{298}^{\ominus}=-172 \mathrm{~kJ} / \mathrm{mol}
\end{gathered}
$$

Water-gas shift reaction:

$$
\mathrm{CO}+\mathrm{H}_{2} \mathrm{O} \rightleftharpoons \mathrm{CO}_{2}+\mathrm{H}_{2}, \Delta \mathrm{H}_{298}^{\ominus}=-41 \mathrm{~kJ} / \mathrm{mol}
$$

Fluidized bed methanation is a key technology to realize cost-effective bio-SNG production at a medium scale [3,4]. This reactor type is able to handle syngas with a wide range of $\mathrm{CO} / \mathrm{H}_{2}$ ratios, from 1 to 5 if water addition is optimized. The advantages of a fluidized bed methanation reactor compared to the fixed bed methanation reactors are the isothermal operation, the easy control, the possibility for the in-situ water gas shift reaction to adjust the $\mathrm{H}_{2} / \mathrm{CO}$ ratio and the low risk of catalyst deactivation due to recirculation of the catalyst particles through the beds. There is a good synergy between DFBG and fluidized bed methanation as both have a moderate operation condition and make production cost reduction possible. Since the methanation reaction equilibrium is reached in both fluidized and fixed bed reactors, the conversion efficiency to SNG is yet expected to be the same, and only the combined heat and power production might differ due to the respective dissimilar heat transfer profiles of the heat exchangers [4]. In present work, the fluidized bed methanation reactor is chosen for modeling BtSNG.

\subsubsection{Upgrading}

The upgrading of bio-SNG is simple compared to other synthetic fuels. A minor part component of $\mathrm{CO}_{2}$ in the product gas needs to be removed. MEA, pressure swing adsorption (PSA) and physical absorption with Selexol are suitable for $\mathrm{CO}_{2}$-removal either up- or downstream of methanation, whereas membranes can only be applied downstream due to the fast permeation of $\mathrm{H}_{2}$. Downstream to these $\mathrm{CO}_{2}$-removal options, a final polysulfone membrane for $\mathrm{H}_{2}$ removal and recycling to the $\mathrm{CH}_{4}$ synthesis reactor has further proven useful to reach the required grid quality of $96 \mathrm{~mol}$. $\% \mathrm{CH}_{4}$ [4].

\subsection{Thermomechanical Pulp (TMP) + Biomass Integrated Gasification Combined Cycle (BIGCC)}

The techno-economic analysis of TMP + BIGCC has been studied previously [7]. Coal-based IGCC technology has been effectively commercialized. Biomass-based IGCC technology, however, is at a pre-commercialization stage, with syngas cleaning as a key issue. In the previous study, DFBG was chosen for biomass gasification. The original CHP plant was replaced by a BIGCC plant.

The results from the TMP + BIGCC study indicated that the TMP + PM electricity consumption cannot be fully made up by the electricity supply from a BIGCC plant with the amount of biomass feedstock corresponding to the amount of pulpwood, even if the TMP SEC goes down by $50 \%$. But the gap becomes fairly small, and much smaller in comparison with the case of a CHP plant. Lower TMP SEC leads to higher economic profit in both the net revenue (NR) and the internal return rate (IRR). The profit of a TMP mill is ranked as: TMP + BIGCC > TMP + CHP > TMP + Boiler. 


\subsection{Simulation with ASPEN Plus}

ASPEN Plus is an excellent modeling tool which is versatile and relatively easy to use. It can be used to model complicated chemical engineering systems. It includes many model blocks to simulate various unit operations. If more sophisticated block ability is required, additional information will be added into the block in a form of FORTRAN subroutines, or an entirely new user block can be created.

The BtSNG model is set up with several ASPEN Plus modules. Each module simulates a unit process. The input data were collected from a variety of sources including experimental and literature data as given in Table 2. The overall mass and energy balance of the integrated mill is examined.

Table 2. Model input data $[4,7,11,15]$.

\begin{tabular}{|c|c|c|c|}
\hline \multicolumn{2}{|c|}{ Lower Heating Value (LHV) Biomass } & \multirow{2}{*}{$(\mathrm{MJ} / \mathrm{kg}, \mathrm{daf})$} & \multirow{2}{*}{$\begin{array}{l}18 \\
80\end{array}$} \\
\hline \multirow{3}{*}{ Efficiency } & Gasification & & \\
\hline & Combustion & \multirow[t]{2}{*}{$(\%)$} & 99 \\
\hline & Boiler & & 75 \\
\hline \multirow{2}{*}{ Drying } & Flue gas inlet & \multirow{2}{*}{$\left({ }^{\circ} \mathrm{C}\right)$} & 550 \\
\hline & Outlet & & 120 \\
\hline Gasification & - & $\left({ }^{\circ} \mathrm{C}\right)$ & $850-900$ \\
\hline \multirow{4}{*}{ Syngas } & Yield & $\left(\mathrm{Nm}^{3} / \mathrm{kg}\right.$ daf biomass $)$ & 1.1 \\
\hline & & & $\mathrm{H}_{2}$ 37.5, $\mathrm{CO} 35.0, \mathrm{CO}_{2}$ 15.0, \\
\hline & Composition & $(\mathrm{vol} \%)$ & $\begin{array}{c}\mathrm{CH}_{4} 8.0, \mathrm{C}_{2} \mathrm{H}_{4} \\
4.0\end{array}$ \\
\hline & LHV & $(\mathrm{MJ} / \mathrm{kg})$ & 13.0 \\
\hline \multirow{2}{*}{ Methanation } & \multirow{2}{*}{ FB } & $\left({ }^{\circ} \mathrm{C}\right)$ & 300 \\
\hline & & (bar) & $5-15$ \\
\hline \multirow{3}{*}{$\begin{array}{c}\text { Purification } \\
\text { (pressure swing } \\
\text { adsorption) }\end{array}$} & $\mathrm{CO}_{2}$ removal & $(\%)$ & $95-99$ \\
\hline & SNG recovery & $(\%)$ & 95-99 \\
\hline & Adsorption pressure & (bar) & 5.5 \\
\hline \multirow{3}{*}{ Steam } & \multirow{3}{*}{ To turbine in PM } & $\left({ }^{\circ} \mathrm{C}\right)$ & 500 \\
\hline & & (bar) & 60 \\
\hline & & (bar) & 2.5 \\
\hline
\end{tabular}

The accessed equations and data were packaged in a specific Property Method set in ASPEN Plus. The involved substances and operation conditions are crucial in choosing a proper Property Method. For gas phase processes, the Peng-Robinson equation of state with Boston-Mathias modification was applied [11,13]. For the H\&P system, the Property Method STEAM-TA was employed $[7,16]$. For the units involving electrolytes, the electrolyte non-random two liquid model, ELECNRTL, in ASPEN Plus was applied.

The gasifier and combustor were modeled with the module "RGibbs" which executes equilibria calculations by Gibbs free energy minimization. When a system does not reach a complete equilibrium state, "RGibbs" can also be used by additionally specifying an extent of equilibrium.

The modeling of the shift reactor is done with an adiabatic Gibbs reactor where $\mathrm{CH}_{4}$ is considered inert and therefore does not take part in the steam reforming [13]. The assumption is considered valid since the shift reactor utilizes a different type of catalyst than the methanation reactor and therefore no methanation or steam reforming should occur in the reactor.

An RGibbs module was used for methanation simulation [11,17]. A temperature approach to equilibrium measure was adopted for the composition calculations in order to account for the deviation from the thermodynamic equilibrium in a real reactor.

A compressor or a turbine was simulated with a module "Compr" which can calculate the power consumed or produced. The heat exchanger was simulated with the module "Heatx", the pump with the module "Pump", and the flow splitter "FSplit".

The ASPEN Plus function block "Design Spec" and in-built "Calculator" were applied for parameters adjustment and process control. In essence, it is a multi-objective optimum design method adopted. This model is based on the following assumptions $[3,4,13,18,19]$ : 
- Biomass devolatilization is instantaneous in comparison with the char gasification;

- The methanation reaction and shift reaction go fast so that the thermodynamic equilibrium is reached;

- The overall CO conversion could approach to $98 \%$;

- $98 \%$ steam is estimated to be condensed;

- The energy required for $\mathrm{CO}_{2}$ removal is considered to be $4.0 \mathrm{MJ} / \mathrm{kg} \mathrm{CO}_{2}$;

- Biomass to SNG energy conversion efficiency $=63 \%$;

- The overall energy conversion efficiency $>90 \%$;

- $\mathrm{CH}_{4}$ concentration $>95 \%$;

- The $\mathrm{CH}_{4}$ losses are about $2.0 \%-4.0 \%$.

\subsection{Economic Evaluation}

The economic profitability of TMP + BtSNG is evaluated in terms of NR (after subtracting the depreciation) and IRR. IRR is also called the discounted cash flow rate of return or the rate of return. IRR disregards the absolute amount of money to be gained, and is an indicator of the efficiency, quality, or yield of an investment. An investment is considered acceptable if its IRR is higher than an established minimum acceptable IRR, 0.1 for instance. Generally, the higher is the IRR and the better the investment.

Table 3. Data for economic analysis $[3,7,11,19,20]$. BIGCC: biomass integrated gasification combined cycle; DDB: Double-Declining Balance method.

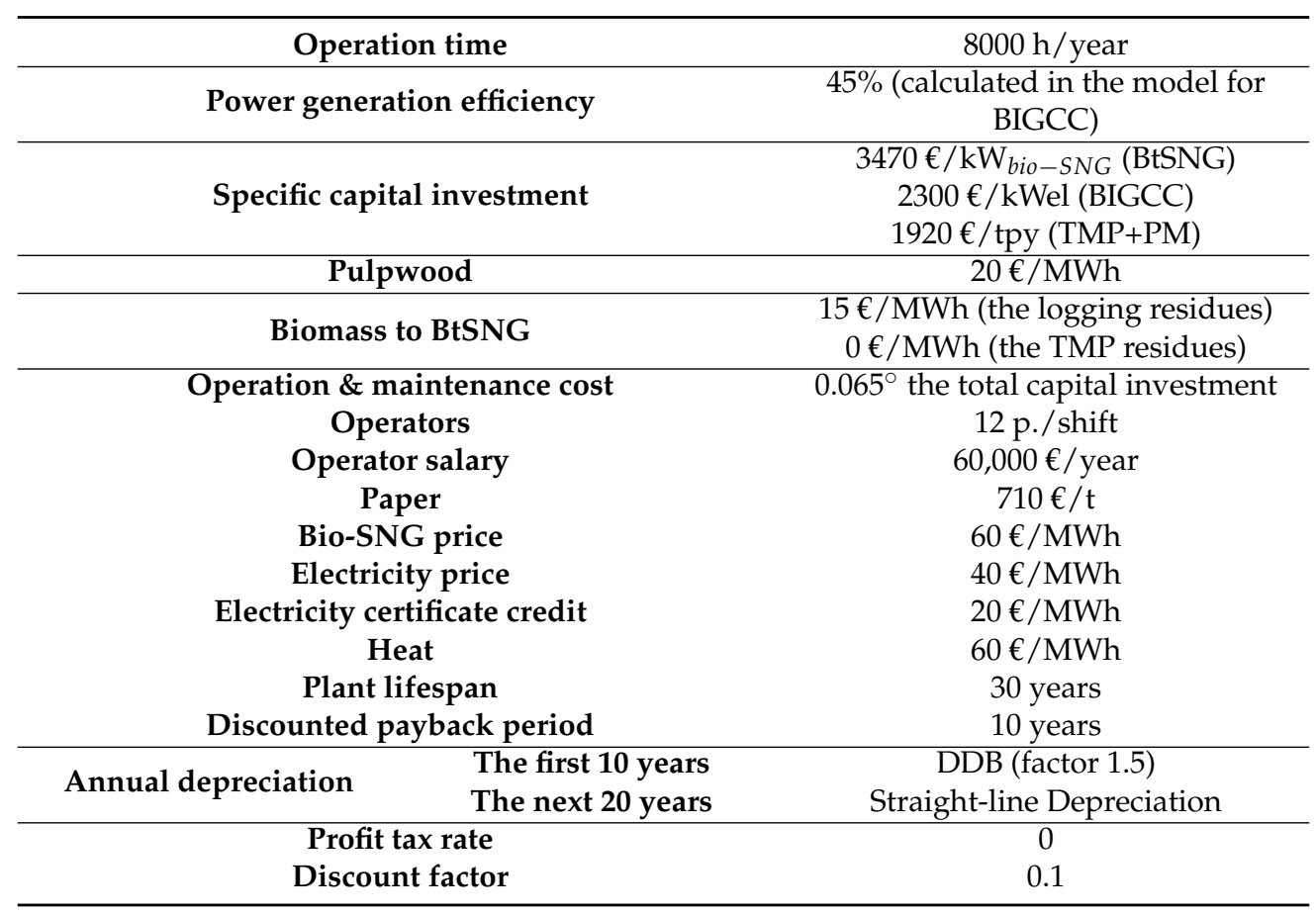

For a TMP + PM mill, its capital investment is about $1920 € /$ tpy [20] for a given paper production capacity as seen in Table 3. The specific capital investment for BIGCC is $2300 € / \mathrm{kWel}$ [21], and for BtSNG $3470 € / \mathrm{kW}_{b i o-S N G}$ [19]. The prices for some facilities are indicated in the literature [10,22]. The operation and maintenance cost accounts for $6.5 \%$ of the capital investment of a combined $\mathrm{TMP}+\mathrm{BtSNG}$ mill. Electricity is purchased at about $40 € / \mathrm{MWh}$. An electricity certificate credit of $20 € / \mathrm{MWh}$ is taken into account. The price of pulpwood is $20 € / \mathrm{MWh}$. The discounted payback period is set as 10 years. The available biomass residues from a TMP mill are free of charge. The overall cost for the logging residues is $15 € /$ MWh in synergy with pulpwood harvesting. The heat 
is sold at $60 € / M W h$ for district heating $(\mathrm{DH})$. The plant lifespan is anticipated to be 30 years. In sensitivity analysis, the bio-SNG is priced at 60 or $120 € / \mathrm{MWh}$, and the pulpwood at $20 € / \mathrm{MWh}$ or $40 € / \mathrm{MWh}$. The other values are unchanged. Two depreciation methods are adopted: for the first 10 years the Double-Declining Balance method (DDB), and for the next years the Straight-line Depreciation method.

\section{Results and Discussion}

\subsection{Implementation of Biomass-to-Synthetic Natural Gas (BtSNG) in a Thermomechanical Pulp (TMP) Mill}

The TMP + BtSNG block flow diagram with an outline of mass and energy input and output is shown in Figure 3. About $100 \mathrm{MW}$ of biomass residues including bark, bio-sludge, reject fibers from TMP and logging residues from pulpwood harvesting in forest are available for bio-SNG production in the TMP + PM mill with a paper production capacity of 250,000 $t$ /year, higher than the pulp used due to addition of chemicals. $63 \mathrm{MW}$ of bio-SNG can be produced, as the bio-SNG yield of BtSNG is estimated to be $63 \%$. The remaining energy of $37 \mathrm{MW}$ of biomass feedstock is carried by flue gas from the combustor, the product gas from the gasifier, the cooling medium from methanation, etc. in the form of heat at different temperatures. This heat energy is recovered to generate $31 \mathrm{MW}$ steam going to the steam cycle in the H\&P centre with $6 \mathrm{MW}$ heat loss. The H\&P centre subsequently supplies $\mathrm{TMP}+\mathrm{PM}$ with 9.5 MW steam and DH with 4.5 MW low temperature heat. The steam cycle in the H\&P centre has a generation efficiency of $20 \%$ and produces $6 \mathrm{MW}$ electricity to meet the demand of $\mathrm{BtSNG}$ for the compression of syngas and bio-SNG, syngas cleaning, $\mathrm{CO}_{2}$ removal, gasifier operation etc. No excess electricity is available from the TMP + PM mill. On the other hand, the H\&P centre can supply TMP + PM with enough steam, 9.5 MW, and 4.5 MW low grade heat energy is recovered as DH. As a result, the H\&P centre has a total efficiency of about $65 \%$, and BtSNG has an overall efficiency of $83 \%$.

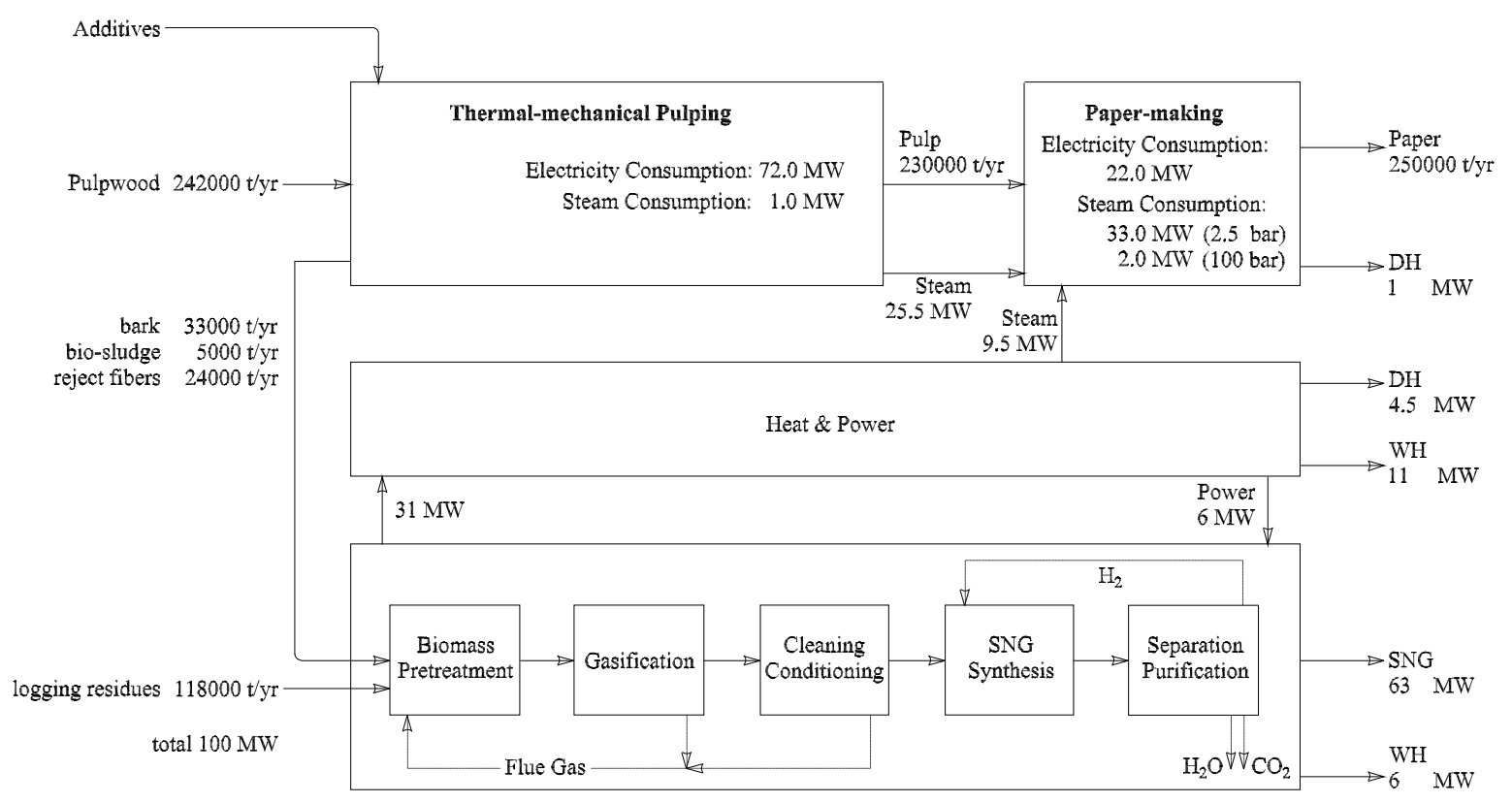

Figure 3. Flowsheet of the TMP + BtSNG process with mass and energy inputs and outputs [23].

Compared to BIGCC, as seen in Figure 4, BtSNG gives almost double yield in terms of energy content, which results in much lower waste heat $(\mathrm{WH})$ and $\mathrm{DH}$. 


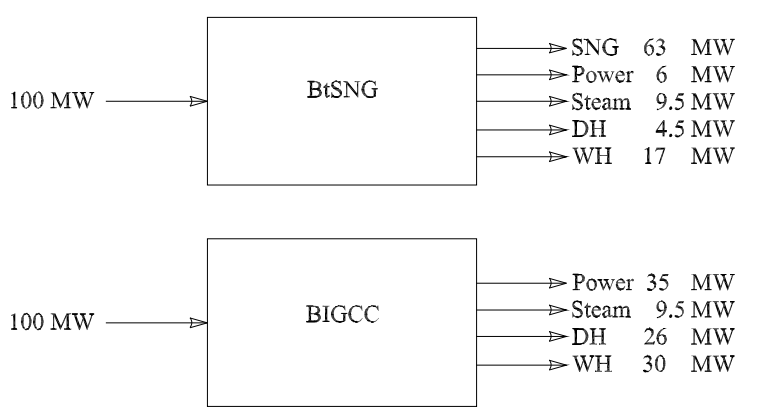

Figure 4. Comparison of BtSNG with BIGCC regarding their outputs in energy content.

The energy balance over the TMP + BtSNG mill is studied by applying the model, in comparison with other two cases of TMP + BIGCC and TMP+ Boiler studied previously [7], as seen in Figure 5.

For the TMP + PM mill studied, the TMP SEC is $2.5 \mathrm{MWh} / \mathrm{bdt}$ pulp, the PM SEC is $0.75 \mathrm{MWh} / \mathrm{bdt}$ pulp, and the steam consumption in the PM is $1.38 \mathrm{MWh} / \mathrm{bdt}$ pulp (see Table 1). The total steam demand is kept constant because of the constant paper throughput, and is provided from the steam energy recovered mainly from the TMP refining process and also from the BtSNG process to a minor degree. The enhancement of refining efficiency lowers the steam yield from TMP. Removal of the reject fibers makes the TMP more energy-efficient, i.e., the TMP SEC is reduced, and the steam yield from TMP is also reduced. A decrease in the steam generation from TMP is compensated for from the BtSNG plant so that the bio-SNG yield may be reduced. The model is designed to ensure that the steam consumption is sufficiently satisfied, as the results indicate in Figure 5. The remaining low-grade energy is utilized in DH. The heat energy for DH is provided from both TMP and BtSNG.

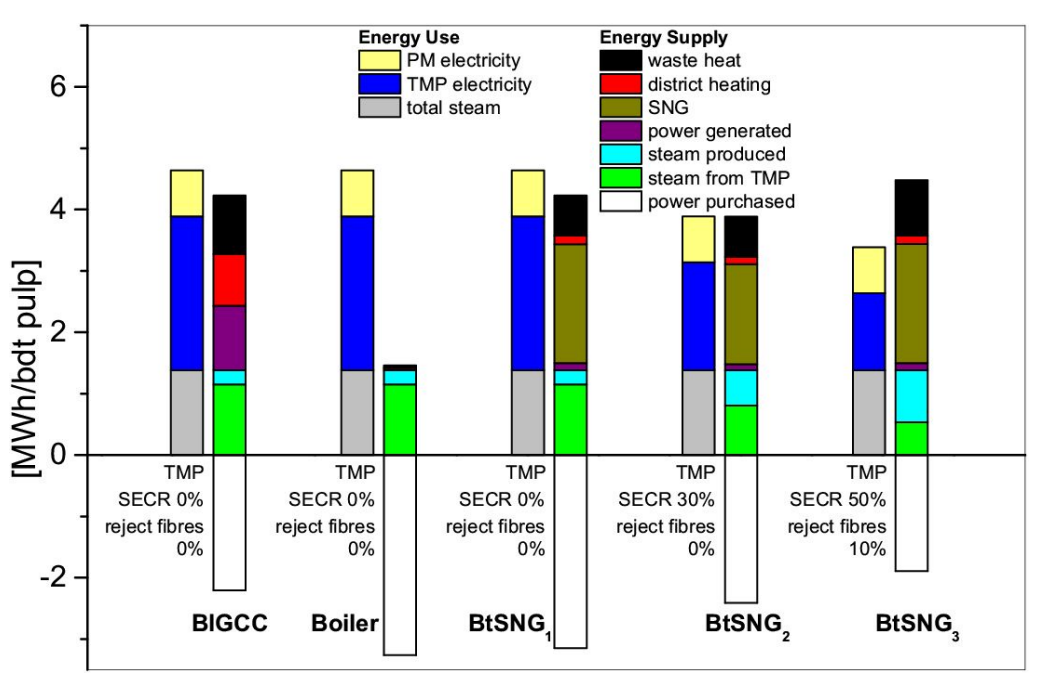

Figure 5. Energy balance when SNG or electricity is produced in a TMP mill [23].

In the Boiler case, which is common for present TMP mills, the TMP biomass residues such as bark, reject fibers are burned to produce the steam needed by PM. No poly-generation is considered by utilizing the large amount of logging residues as seen in Figure 5.

Compared with the case of BIGCC, BtSNG 1 gives almost double product yield in energy content and much less $\mathrm{DH}$ and $\mathrm{WH}$, so that the overall energy efficiency is high, but more electricity will need to be purchased.

In the case of $\mathrm{BtSNG}_{2}$ when the reduction of SEC (SECR) is raised from $0 \%$ to $30 \%$, the steam generated from TMP refining is reduced, and more steam production from BtSNG is required. The steam demand exceeds the steam provided by BtSNG under normal operation condition of 
maximizing bio-SNG production. Thus a part of syngas will be burned to provide steam, which gives rise to a lower bio-SNG yield.

In the case of $\mathrm{BtSNG}_{3}$ when the SECR is raised to $50 \%$ by $10 \%$ fibre rejection, the bio-SNG yield is increased back to the level of the $\mathrm{BtSNG}_{1}$ case in spite of more syngas going to steam production. This is attributed to the $10 \%$ reject fibers leading to twofold impacts: (1) direct addition of $10 \%$ reject fibers as feedstock to BtSNG and (2) indirect addition of total biomass residues to the gasifier. The usable biomass is $3.1 \mathrm{MWh} / \mathrm{bdt}$ pulp including the logging residues, bark, and bio-sludge, and is $3.9 \mathrm{MWh} / \mathrm{bdt}$ pulp further including the $10 \%$ reject fibers. The paper yield will be kept by adding more pulpwood though the reject fibers are moved out.

\subsection{Economic of Scale}

The above analysis of energy balance over the TMP + BtSNG mill is based on a typical scale of TMP + PM mills with a paper production capacity of 250,000 $t$ /year. The corresponding scale of the BtSNG plant is about $100 \mathrm{MW}$ of biomass thermal input as seen in Figures 1 and 3 . The scale of the BtSNG will be taken to represent the whole scale of the TMP + BtSNG mill for economic analysis as shown in Figure 6.

As seen in Figure 6a, the bio-SNG production per ton of pulp holds constant against the scale, which indicates a linear relationship between the bio-SNG production and the TMP pulp output. The steam produced from the H\&P centre associated to the BtSNG plant is fairly limited in comparison with the BIGCC plant, but still can meet the demand of the TMP + PM mill as shown in Figure $6 \mathrm{~b}$. Very little heat energy is available for $\mathrm{DH}$, which can also be observed from Figure 5.

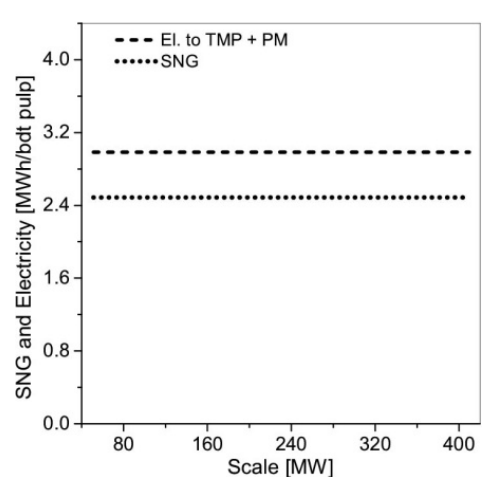

(a)

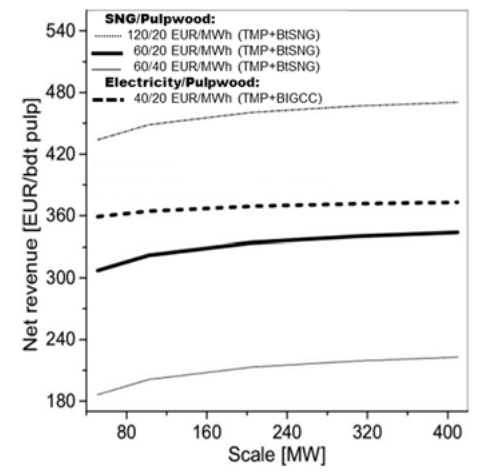

(c)

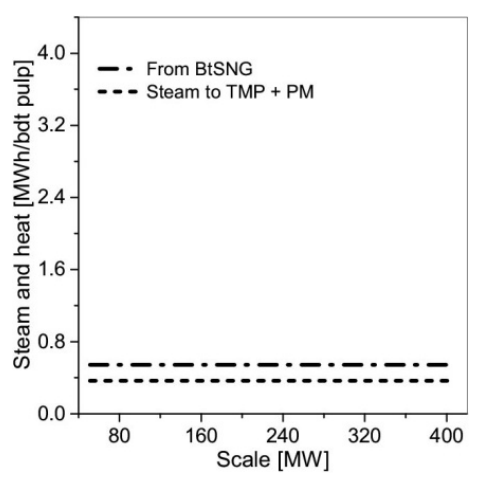

(b)

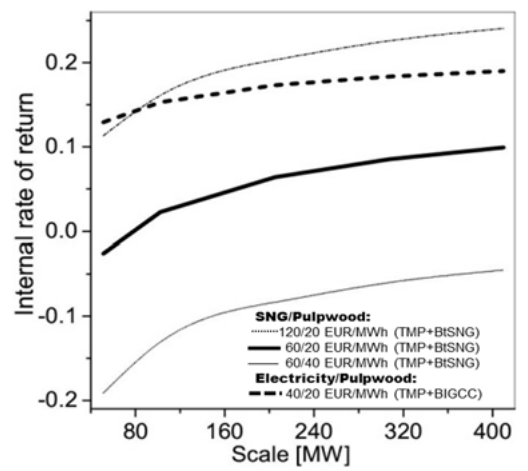

(d)

Figure 6. Effect of the BtSNG plant scale as the biomass thermal input.

The economic profitability is sensitive to both the SNG price and the pulpwood price as seen in Figure $6 c, d$. When the SNG price is doubled, the IRR increases from about $2 \%$ to about $16 \%$. When 
the pulpwood price is doubled, the IRR decreases from about $2 \%$ down to about $-13 \%$. The NR and IRR increase with the plant scale and level off after $100 \mathrm{MW}$.

Compared to the results of the case of TMP + BIGCC, represented by the dashed curves in Figure $6 c, d$, the NR and IRR of TMP + BtSNG are much lower. This is attributed to three reasons: (1) the specific investment cost is much higher for BtSNG; (2) the electricity certificate instrument in Sweden has added a credit to the electricity production; and (3) much more $\mathrm{DH}$ is produced by BIGCC, and DH has a price unusually high (higher than electricity used in industries in Sweden, which has a very low tax comparing to heavy tax for the electricity used in the domestic sector such as DH system).

In summary, plant scale and SNG price are two strong factors for the implementation of BtSNG in a TMP mill. A BtSNG plant associated to a TMP mill should be built at a scale above $100 \mathrm{MW}$ in biomass thermal input. Political instruments to support commercialization of transport biofuel are necessary.

\subsection{Reject Fibers to Gasifier}

Usually in TMP mills, up to about $10 \mathrm{wt} \%$ of the pulp fibers have properties that are not good enough to remain in the final product, and they may be removed as reject fibers. They can be utilized as feedstock to biomass gasifiers. $20 \%$ TMP SECR should be possible when taking out the fibers with respect to final paper product properties [6].

As seen in Figure 7a, with the amount of reject fibers, the bio-SNG yield per ton of pulp clearly increases for two reasons: (1) the reject fibers are directly added in the gasifer; and (2) the usable biomass residues increase as the product paper output is kept constant. Corresponding to the increase in feedstock, the amount of steam and heat produced from BtSNG increases as well. At the same time, the steam demand by the TMP + PM mill also increases since the low quality fibers rejection possibly leads to a lower TMP SEC and less steam supply from TMP to PM. Thus, the steam demand by $\mathrm{TMP}+\mathrm{PM}$ is well balanced with the steam supply from BtSNG.

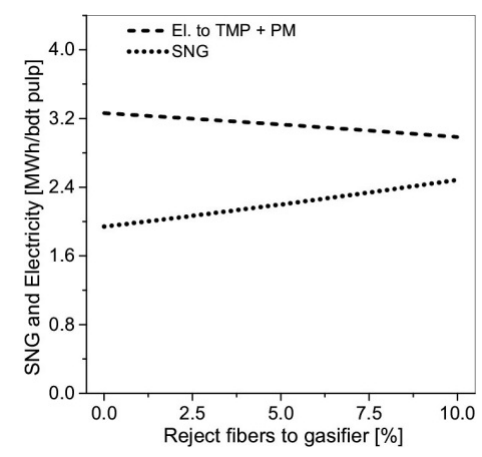

(a)

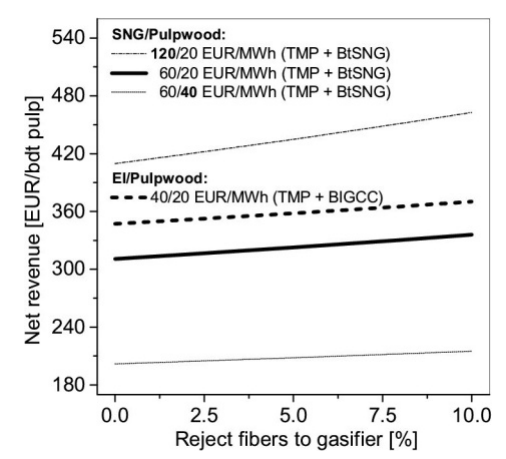

(c)

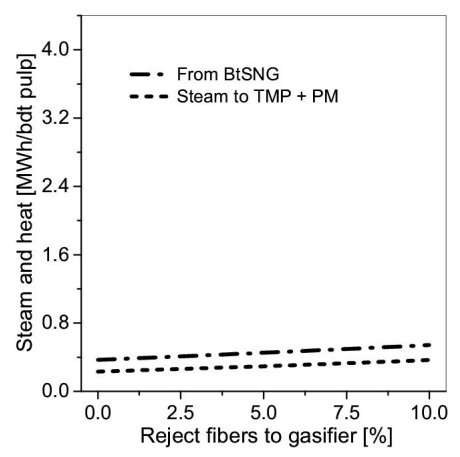

(b)

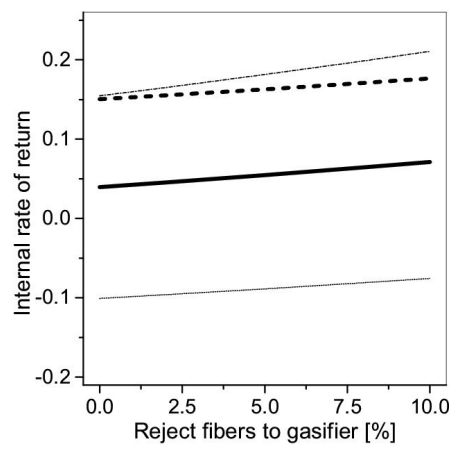

(d)

Figure 7. Effect of adding reject fibres. 
Figure $7 \mathrm{c}, \mathrm{d}$ shows that the NR and the IRR values increase with the amount of the reject fibers. This can be explained by several factors: (1) more SNG is generated as more reject fibers are added; (2) the TMP SEC is cut down; (3) the paper yield is held by supplementing pulpwood. Compared to the case of TMP + BIGCC, TMP + BtSNG shows a much lower profitability for the same reasons mentioned above.

\subsection{Improved Electric Energy Efficiency of Thermomechanical Pulp (TMP)}

TMP SEC is a key factor in the high cost pulp production. A 50\% SECR is targeted. The SECR is indicated by the dashed line in Figure 8a. With SECR, less steam can be supplied from TMP. BtSNG must make up the balance (Figure $8 b$ ). The availability of biomass for the conversion from biomass to SNG will therefore be lowered (Figure 8a), and the steam provided from BtSNG to TMP + PM increases as shown in Figure 8b. In some TMP + PM mills, a backup boiler is specially used to supply steam without self-production of electricity. In the TMP + Boiler case, a proper amount of biomass will be fed into for offering PM a certain amount of steam. In the case of TMP + BtSNG, more steam than normal supply from the BtSNG plant must be produced at the expense of bio-SNG yield.

As shown in Figure 8c,d, lower TMP SEC leads to higher economic profit in both NR and IRR. For NR, TMP + BIGCC > TMP + BtSNG > TMP + Boiler, but for IRR, TMP + BIGCC > TMP + Boiler $>\mathrm{TMP}+\mathrm{BtSNG}$. In the transport markets of Sweden where the natural gas price is relatively high and the feedstock supply is good, we are likely to see the first installation of commercial S\&M scale bio-SNG production. However, since the biomethane market in Sweden is far from mature, it is still heavily dependent on political ambitions and associated instruments, as well as regional and local initiatives and a relatively high natural gas price.

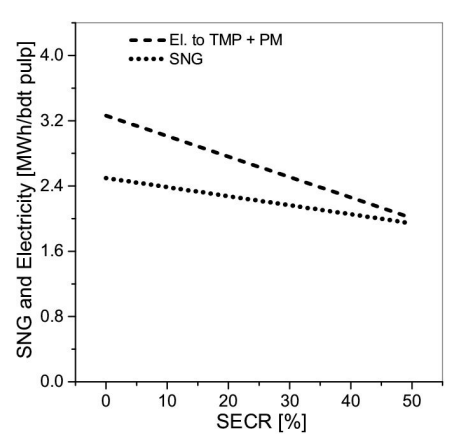

(a)

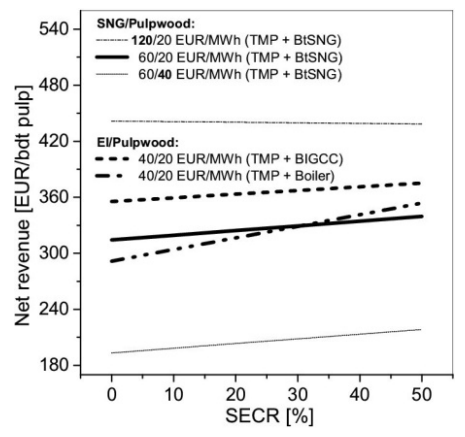

(c)

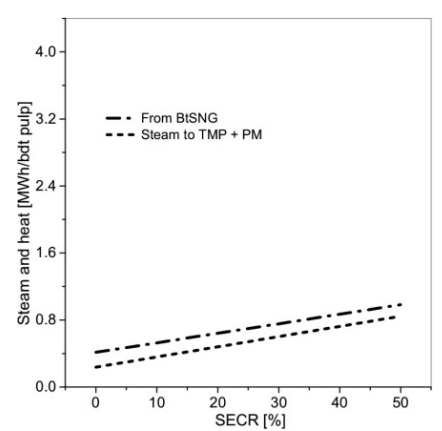

(b)

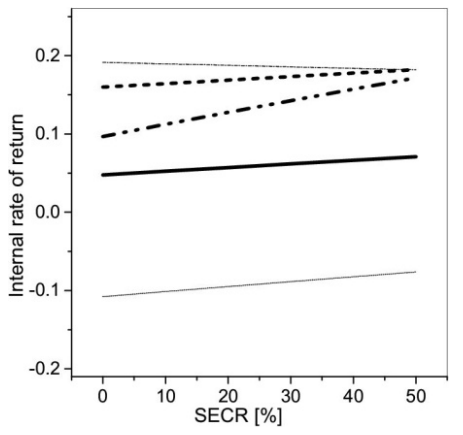

(d)

Figure 8. Effect of reducing the TMP specific electricity consumption.

\section{Conclusions}

A TMP + BtSNG mathematical model is developed based on the economic conditions in Sweden. The profitability of the TMP + BtSNG mill is evaluated in comparison with the TMP + BIGCC mill. The model prediction can be concluded as below: 
The scale of the TMP + BtSNG mill and SNG price are two strong factors for the implementation of BtSNG in a TMP mill. A BtSNG plant associated to a TMP mill should be built at a scale above $100 \mathrm{MW}$ of biomass thermal input.

Compared to the case of TMP + BIGCC, the NR and IRR of TMP + BtSNG are much lower. This is attributed to three reasons: (1) the specific investment cost is much higher for BtSNG; (2) The electricity certificate instrument in Sweden has added a credit to the electricity production; and (3) Much more DH is produced by BIGCC, which has an unusually high price (higher than electricity) in Sweden. Political instruments to support commercialization of transport biofuel are necessary. For countries where the heat price is lower, TMP + BtSNG will be more profitable.

Acknowledgments: The authors would like to acknowledge the project support of EU regional structure fund, Ångpanneföreningen Foundation for Research and Development, LKAB, Länsstyrelsen Västernorrland and Swedish Gasification Center (SFC).

Author Contributions: Wennan Zhang and Jie He developed and designed the process flow diagram as well as the physical and mathematical model. Per Engstrand and Olof Björkqvist provided information and data about biomass availability and process design in thermomechanical pulp mills. All authors participated the paper preparation and improvement.

Conflicts of Interest: The authors declare no conflict of interest.

\section{Abbreviations}

\begin{tabular}{ll} 
bdt & bone dry ton \\
BIGCC & biomass integrated gasification combined cycle \\
bio-SNG & SNG produced from biomass / biofuel \\
BtSNG & biomass to SNG \\
CHP & combined heat and power \\
CTMP & chemithermomechanical pulp \\
daf & dried and ash free \\
DDB & double declining balance depreciation method \\
DFBG & dual fluidized bed gasifier \\
DH & district heating \\
DIP & deinked pulp \\
FB & fluidized bed \\
H\&P & heat and power \\
HYP & high-yield pulp \\
IRR & internal return rate \\
LHV & lower heating value \\
NR & net revenue \\
PGW & pressure groundwood \\
PM & paper mill \\
SEC & specific electricity consumption \\
SECR & reduction of SEC, \% \\
SGW & stone groundwood \\
SNG & synthetic natural gas \\
S\&M & small and medium \\
TMP & thermomechanical pulp \\
tpy & ton per year \\
WH & waste heat \\
\hline
\end{tabular}

\section{References}

1. Zhang, W. Automotive fuels from biomass via gasification. Fuel Process. Technol. 2010, 91, 866-876. [CrossRef]

2. Dry, M.E. High quality diesel via the Fischer-Tropsch process-A review. J. Chem. Technol. Biotechnol. 2002, 77, 43-50. [CrossRef] 
3. Held, J. Small and Medium Scale Technologies for Bio-SNG Production; Svenskt Gastekniskt Center: Malmö, Sweden, 2013.

4. Gassner, M.; Marechal, F. Thermo-economic optimisation of the polygeneration of synthetic natural gas (SNG), power and heat from lignocellulosic biomass by gasification and methanation. Energy Environ. Sci. 2012, 5, 5768-5789. [CrossRef]

5. Engstrand, P.; Jonsson, J.; Sandberg, C.; Starck, G.; Wancke-Stahl, C.; Wahlgren, M. Method of Producing Bleached Thermomechanical Pulp (TMP) or Bleached Chemithermomechanical Pulp (CTMP). WO Patent WO/2003/000,982, 2003.

6. Westermark, U.; Capretti, G. Influence of ray cells on the bleachability and properties of CTMP and kraft pulps. Nord. Pulp Paper Res. J. 1988, 3, 95-99. [CrossRef]

7. He, J.; Engstrand, P.; Björkqvist, O.; Zhang, W. Techno-economic evaluation of a mechanical pulp mill with gasification. Nord. Pulp Paper Res. J. 2013, 28, 349-357. [CrossRef]

8. Pettersson, J. Energy survey for energy management-Holmen Paper, Hallsta. Available online: http:/ / epubl.ltu.se/1402-1617/2005/109/LTU-EX-05109-SE.pdf (accessed on 23 September 2012).

9. Göransson, K.; Söderlind, U.; He, J.; Zhang, W. Review of syngas production via biomass DFBGs. Renew. Sustain. Energy Rev. 2011, 15, 482-492. [CrossRef]

10. Phillips, S.; Aden, A. Thermochemical Ethanol via Indirect Gasification and Mixed Alcohol Synthesis of Lignocellulosic Biomass; National Renewable Energy Laboratory: Golden, CO, USA, 2007.

11. Heyne, S. Bio-SNG from Thermal Gasification-Process Synthesis, Integration and Performance. Ph.D Thesis, Chalmers University of Technology, Göteborg, Sweden, 2013.

12. Tunå, P. Substitute Natural Gas from Biomass Gasification; Svenskt Gastekniskt Center: Malmö, Sweden, 2008.

13. Agersborg, J.; Lingehed, E. Integration of Power-to-Gas in Gasendal and GoBiGas. Master's Thesis, Chalmers University of Technology, Göteborg, Sweden, 2013.

14. Bader, A.; Bauersfeld, S.; Brunhuber, C.; Pardemann, R.; Meyer, B.; Siemens, A.G.; Solutions, E. Modelling of a chemical reactor for simulation of a methanisation plant. In Proceedings of the 8th International Modelica Conference, Dresden, Germany, 20-22 March 2011.

15. He, J.; Göransson, K.; Söderlind, U.; Zhang, W. Simulation of biomass gasification in a dual fluidized bed gasifier. Biomass Convers. Biorefinery 2012, 2, 1-10. [CrossRef]

16. He, J.; Zhang, W. Techno-economic evaluation of thermo-chemical biomass-to-ethanol. Appl. Energy 2011, 88, 1224-1232. [CrossRef]

17. Porubova, J.; Bazbauers, G.; Markova, D. Modeling of the Adiabatic and Isothermal Methanation Process. Sci. J. Riga Tech. Univ. Environ. Clim. Technol. 2011, 6, 79-84. [CrossRef]

18. Zwart, R.; Boerrigter, H.; Deurwaarder, E.P.; van der Meijden, C.M.; van Paasen, S.V.B. Production of Synthetic Natural Gas (SNG) from Biomass; Energy Research Centre of the Netherlands (ECN): Petten, The Netherlands, 2006.

19. Thunman, H.; Alamia, A.; Berguerand, N.; Lind, F.; Seemann, M. Beyond 80\% Efficiency for Standalone Production of Bio-Methane from Wet Biomass; Chalmers University of Technology: Göteborg, Sweden, 2014.

20. Holmberg, J.M.; Gustavsson, L. Systems aspects on new energy technologies in the pulp and paper industry. In Proceedings of the 3rd International Green Energy Conference IGEC-III, Västerås, Sweden, 18-20 June 2007.

21. Wetterlund, E.; Söderström, M. Biomass gasification in district heating systems-The effect of economic energy policies. Appl. Energy 2010, 87, 2914-2922. [CrossRef]

22. Eriksson, G.; Kjellström, B. Assessment of combined heat and power (CHP) integrated with wood-based ethanol production. Appl. Energy 2010, 87, 3632-3641. [CrossRef]

23. He, J.; Engstrand, P.; Björkqvist, O.; Zhang, W. Bio-SNG production in a TMP mill in comparison with BIGCC. Energy Procedia 2014, 61, 2894-2897. [CrossRef]

(C) 2015 by the authors; licensee MDPI, Basel, Switzerland. This article is an open access article distributed under the terms and conditions of the Creative Commons by Attribution (CC-BY) license (http://creativecommons.org/licenses/by/4.0/). 